\title{
KERYGMATYCZNY WYMIAR NAUCZANIA O WCIELENIU U GRZEGORZA Z NAZJANZU
}

Grzegorz z Nazjanzu († 390) za wybitne zasługi dla rozwoju myśli teologicznej został przez potomnych nazwany „Teologiem”, mimo że nie napisał żadnego traktatu dogmatycznego, nie pozostawił jakiegokolwiek komentarza egzegetycznego, nie był też mistrzem którejkolwiek ze szkół teologicznych. Jego spuścizna literacka obejmuje Listy kierowane do pojedynczych dobrze znanych mu osób, Poematy przeznaczone dla odbiorców zainteresowanych poezją i Mowy wygłaszane do szerszego, po części anonimowego, grona słuchaczy. Co zatem sprawiło, że jego refleksja teologiczna rozproszona na kartach wymienionych dzieł stała się tak szybko zauważalna przez wytrawnych znawców ówczesnej teologii? Niewątpliwym jego atutem była sztuka operowania słowem, którą zdobył podczas studiów retoryki w Atenach. Umiejętność przekazywania prawd wiary i wyjaśniania zawiłych twierdzeń teologicznych dostrzegana jest przede wszystkim w jego mowach, które wygłaszał u boku swego ojca do mieszkańców Nazjanzu, a zwłaszcza jako biskup Konstantynopola do mieszkańców stolicy.

W swym pasterskim nauczaniu podejmował różne zagadnienia. Ważnym tematem, nurtującym dociekliwy umysł Grzegorza i odpowiedzialną duszę pasterza, była również tajemnica wcielenia, której poświęcił stosunkowo dużo miejsca w swej twórczości. W tym kontekście trzeba nawet stwierdzić, że Grzegorz z Nazjanzu jest autorem najstarszego zachowanego w literaturze wczesnochrześcijańskiej kazania o Bożym Narodzeniu ${ }^{1}$, którym jest Mowa 38, wygłoszona na uroczystość Bożego Narodzenia 379 roku² $^{2}$. Dla Grzegorza, od kilku miesięcy biskupa Konstantynopola, pojawiła się więc doskonała okazja, by $z$ racji obecności $w$ tym mieście zwolenników arianizmu i apolinaryzmu podać zdezorientowanym chrześcijanom, narażonym na zgubne wpływy tych herezji,

${ }^{1}$ Por. J.M. Szymusiak, Grzegorz Teolog. U źródet chrześcijańskiej myśli IV wieku, Poznań 1965, 174; J. Mossay, Les fêtes de Noël et d'Épiphanie d'après les sources littéraires Cappadociens du IV siècle, Louvain 1965.

2 J.M. Szymusiak, Pour une chronologie des discours de S. Grégoire de Nazianze, VigCh 20(1966)183-189. 
wykładnię prawdy o wcieleniu. Doskonale zdawał sobie sprawę z okoliczności, w jakich przyszło mu żyć i nauczać. Jego pasterska działalność była krytykowana, a on sam stał się celem nawet fizycznych ataków ${ }^{3}$. Musiał zatem strzec się swoich przeciwników, czyhających na słowne „potknięcia” w wygłaszanych kazaniach, by nie okazały się pożywką dla niepotrzebnych dyskusji i polemik. Przede wszystkim jednak miał na uwadze chrześcijan powierzonych jego pasterskiej trosce, do których tak często przemawiał, przekazując i wyjaśniając kerygmat apostolski. W ciągu dwóch lat posługiwania biskupiego w Konstantynopolu (379-381) wygłosił aż połowę z 45 zachowanych mów.

Mowa 38, jak już wspomniano, należy do mów konstantynopolitańskich i najobszerniej przedstawia tajemnicę wcielenia, ujętą raczej w formę katechezy niż w spekulatywny traktat. Błędnowiercy głosili wówczas teorię, że Jezus Chrystus ma tylko jedną naturę, dlatego też teza ta stała się punktem odniesienia wyjaśnień Grzegorza, będących swoistą polemiką ukrytą pod powłoką retoryki. Biskup najpierw wyraża głęboką radość z racji obchodzonego święta i zachęcając do tego samego swoich słuchaczy, nawołuje: „Chrystus się rodzi, wielbijcie Go; Chrystus z nieba przychodzi, wyjdźcie Mu na spotkanie; Chrystus na ziemi, wznieście się na wyżyny niebios", po czym dodaje słowami Pisma Świętego: „Śpiewajcie Panu, wszystkie krainy” (Ps 96,1), „niech cieszy się niebo i ziemia raduje” (Ps 96,11), a to dlatego ,gdyż Pan niebios staje się mieszkańcem ziemi. Chrystus przybrał ciało - z drżeniem i radością wykrzykujcie" ${ }^{4}$. Te słowa, którymi biskup wzywa uczestników liturgii do radosnego przeżywania święta, kryją w sobie i jednocześnie zapowiadają podwójne spojrzenie na Jezusa Chrystusa. Ta dwubiegunowość została bowiem wyrażona kilkoma krótkimi stwierdzeniami: „Chrystus z nieba” - „Chrystus na ziemi”, „cieszy się niebo i ziemia raduje”, „Pan niebios [...] mieszkańcem ziemi”, „Chrystus przybiera ciało". Wynika z nich, że w Jezusie Chrystusie spotkały się dwie rzeczywistości, jakimi są niebo i ziemia, co wielokrotnie Grzegorz akcentuje.

Te dwa ,żywioły”, jak nazywa je Kapadocczyk, zostaną w dalszej części mowy dokładniej opisane jako te, które spotkały się w Nowonarodzonym. Stąd też biskup w sposób bardziej bezpośredni pragnie najpierw obwieścić sens przeżywanej uroczystości:

„Ja zaś ogłoszę znaczenie tego dnia: Bezcielesny przyjmuje ciało, Słowo się materializuje, niewidzialny daje się widzieć, nietykalny daje się dotknąć, bezczasowy poczyna się w czasie, Syn Boga staje się synem człowieczym"6.

${ }^{3}$ Więcej na ten temat podają: J. Mossay, Gregor von Nazianz in Konstantinopol (379-381), „Byzantion” 47(1977)223-238; R.E. Snee, Gregory Nazianzen's Constantinopolitan Career, Washington 1981; G.C. Papademetriou, Gregory the Theologian: Patriarch of Constantinople, GOThR 39(1994)1-6.

${ }^{4}$ Oratio 38, 1, SCh 358, 104, w. 2, thum. zbiorowe: Mowy wybrane (dalej: Mowy), Warszawa 1967, 415

5 Por. Oratio 38, 1, SCh 358, 104, w. 3, Mowy, s. 416. 
Tę wypowiedź charakteryzuje zarówno prostota dobranych słów, jak i głębia zawartej $\mathrm{w}$ nich treści, która bez wątpienia odnosi się do dwóch natur w Chrystusie. Mówca, objaśniając znaczenie święta, musiał być bardzo ostrożny w wypowiadanych przez siebie opiniach, w których pragnął przede wszystkim podkreślić istnienie obu natur w Chrystusie. Unikał, czego dowodzi powyższy tekst, spekulatywnych pojęć i w sposób bardzo przystępny objaśniał istotę obchodzonego wspólnie z wiernymi święta.

Przytoczoną wyżej wypowiedź Grzegorz poprzedził nawiązaniem do postaci Melchizedeka, będącego figurą Chrystusa w tym znaczeniu, że ów kapłan Starego Testamentu nie miał ojca i matki. Stąd słowa biskupa: „Dopełnia się postać Melchizedeka: ten, co był bez matki, jest bez ojca, bez matki pierwej, bez ojca wtórnie"7. Treść tego stwierdzenia jest również wskazaniem na dwie natury Chrystusa i jednocześnie wyjaśnieniem ich pochodzenia. Swoje obrazowe wyjaśnienia Grzegorz przeplata napomnieniami, z których jedno kieruje do przeciwników, parafrazując słowa biblijne: ,Lud, siedzący w ciemności niewiedzy (Iz 9,2), niech zobaczy wielkie światło poznania" , a drugie do uczestników liturgii: „Prawa natury zostały obalone. [...], nie sprzeciwiajmy się"

Opisywana tu dwubiegunowość stwierdzeń biskupa widoczna jest w interpretacji dwóch nazw, odnoszących się do obchodzonego święta. Są to: Boże

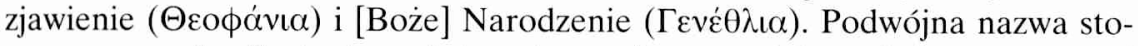
sowana na określenie tego święta jest związana także z dwiema naturami

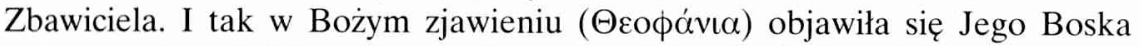
natura, ponieważ, jak stwierdza Grzegorz, „Bóg zjawił się ludziom przez urodzenie, jednym już będąc i zawsze będąc z będącego zawsze" 10 , natomiast

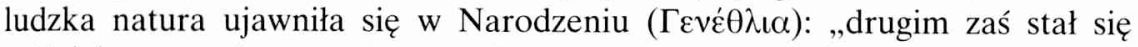
później z powodu nas, aby Ten, który dał nam byt, [...] znowu zaprowadził do siebie przez wcielenie"11. Zwrócenie przez Grzegorza uwagi na istnienie podwójnej nazwy tego samego święta było z pewnością podyktowane burzliwymi dyskusjami ze zwolennikami teologii ariańskiej i apolinarystycznej, którzy w sposób niewłaściwy pojmowali podwójność natur w Chrystusie i wręcz jej zaprzeczali. Tym samym miało to podważyć ich błędną koncepcję rozumienia natur. Definicje wymienionych nazw są bardzo opisowe i proste w swej konstrukcji, by odbiorcy tych słów, zwłaszcza ci niewykształceni, mogli je łatwo zrozumieć i zaakceptować.

Zatem prostota wypowiedzi i powoływanie się na autorytet Pisma Świętego w czasie obwieszczania przez biskupa znaczenia święta, to elementy współtwo-

${ }^{6}$ Oratio 38, 2, SCh 358, 106, w. 16-18, Mowy, s. 416.

7 Oratio 38, 2, SCh 358, 106, w. 7-9, Mowy, s. 416.

${ }^{8}$ Oratio 38, 2, SCh 358, 104, w. 3-4, Mowy, s. 416.

9 Oratio 38, 2, SCh 358, 106, w. 9-10, Mowy, s. 416.

${ }^{10}$ Oratio 38, 3, SCh 358, 108, w. 3-5, Mowy, s. 416.

11 Oratio 38, 3, SCh 358, 108, w. 6-9, Mowy, s. 416. 
rzące tzw. katechezę kerygmatyczną, stosowaną przez mówcę dla wzbudzenia w słuchających zainteresowania przeżywaną tajemnicą dnia, a także w celu podania im podstawowej wiedzy. Jednak w zakończeniu drugiej z wyżej podanych definicji Grzegorz ośmielił się po raz pierwszy i jedyny użyć w tej mowie

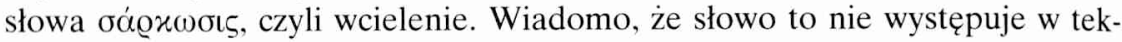
stach Nowego Testamentu, a wprowadzone zostało do języka teologicznego przez Ireneusza $z$ Lyonu ${ }^{12}$. W wyniku derywacji słowotwórczej zostało ono

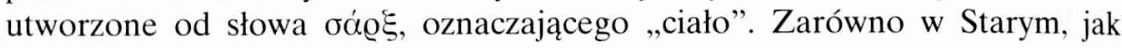
i Nowym Testamencie, ciało w odniesieniu do człowieka przedstawia go ze strony zewnętrznej, ziemskiej, a także może ono oznaczać człowieka jako całość, czyli osobę ludzką ${ }^{13}$. Takie znaczenie jest również zawarte w słowie

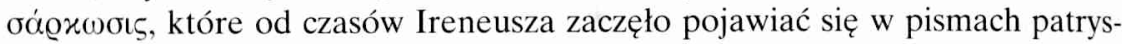
tycznych. Znał je również Grzegorz i być może część jego słuchaczy.

Interesującym jest to, że Kapadocczyk użył tego słowa już w Mowie 2, wygłoszonej w 362 roku, a zatem na początku swego posługiwania kapłańskiego $^{14}$. Pojawia się ono w wypowiedzi, która sygnalizuje to, by wiedzieć, czego nauczać „o jednym i drugim Testamencie, o pierwszym przyjściu Chrystusa i o paruzji, o wcieleniu i o męce oraz o Zbawieniu, o powszechnym zmartwychwstaniu, o końcu świata, o sądzie ostatecznym i o wynagrodzeniu za

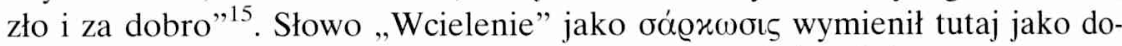
brze znany termin o zabarwieniu judaistycznym, co już wyżej zaznaczono.

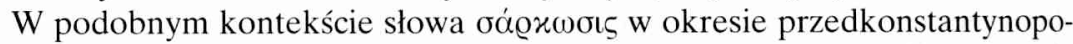
litańskim Grzegorz użył jeszcze tylko w Mowie 4, nie wygłoszonej inwektywie przeciw Julianiowi, powstałej w Poncie pod koniec 363 r. (lub na początku 364 r. $)^{16}$. Wymieniając $w$ niej cudowne interwencje Boga, stawia pytanie: „A po cóż mamy wyliczać po kolei, jakich cudów dokonał sam Chrystus w czasie swej zbawczej obecności w czasie wcielenia, co po Nim i poprzez Niego dokonali święci apostołowie Jego i sługi słowa [Bożego]?"17. Zatem, jak to pokazuje przytoczony tekst, termin ten pojawia się tylko okazjonalnie.

Natomiast kolejnym etapem katechezy o Bożym Narodzeniu w Mowie 38 jest podanie słuchającym szczegółowego wyjaśnienia obchodzonego święta, czyli istoty wcielenia. Najpierw jednak mówca obwieszcza im intencję dalszego

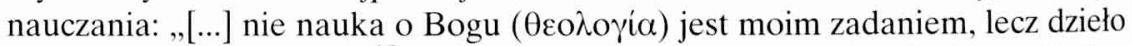
odkupienia (oixovouia)"18. Tego typu oddzielenie teologii od ekonomii zba-

${ }^{12}$ Por. Adversus haereses III 19,1.

13 Por. X. Leon-Dufour, Ciało, w: tenże (red.), Słownik teologii biblijnej, thum. K. Romaniuk, Poznań-Warszawa 1982, 140.

14 Por. Szymusiak, Grzegorz Teolog, dz. cyt., 72.

15 Oratio 2, 36, SCh 247, 134, w. 2-6, Szymusiak, Grzegorz Teolog, dz. cyt., 267.

16 Por. Szymusiak, Grzegorz Teolog, dz. cyt., 124 (przypis 29).

17 Oratio 4, 19, SCh 309, 112, w. 14-18, Mowy, s. 71.

18 Oratio 38, 8, SCh 358, 118, w. 12-14, Mowy, s. 419. 
wienia pojawiło się już przed Grzegorzem ${ }^{19}$, co potem na stałe utrwaliło się w nauczaniu Ojców Wschodnich, mimo pojawienia się pewnych tendecji ujmowania tych zagadnień całościowo ${ }^{20}$. Biskup Konstantynopola, będąc przedstawicielem tego nurtu na Wschodzie ${ }^{21}$, pojmował ekonomię zbawienia jako całokształt ingerencji Bożych, począwszy już od stworzenia. Znaczna część Mowy 38 jest właśnie opisaniem tych wydarzeñ ${ }^{22}$. Mówca przedstawił słuchaczom wydarzenia ze Starego Testamentu, które przede wszystkim dotyczyły stworzenia świata i człowieka oraz popełnienia przez niego grzechu pierworodnego wraz ze wszystkimi tego konsekwencjami po to, by łatwiej zrozumieli sens tajemnicy wcielenia. Mówiąc inaczej, Grzegorz rozpatruje tajemnicę wcielenia w kontekście nauki o stworzeniu i upadku człowieka. Nauczając o tym i w taki sposób, miał na uwadze zwłaszcza ludzi prostych, dlatego opis tych wydarzeń jawi się bardziej jako oratorski dyskurs niż spekulatywny wykład.

Po przedstawieniu tego etapu ekonomii zbawczej biskup Konstantynopola przechodzi do opisania najważniejszego jej wydarzenia, jakim był sam fakt wcielenia. Ma przy tym świadomość, że nie może posługiwać się terminologią zbyt wyszukaną, niejasną, chcąc być właściwie zrozumianym przez słuchaczy. Toteż najpierw w prostych i przystępnych wyrażeniach opisuje Słowo Boga, objaśniając je jako: „przedwieczne, niewidzialne, nieuchwytne, bezcielesne, początek początków, światłość ze światłości, źródło żywota i nieśmiertelności, odbicie piękności pierwowzoru, nienaruszalna pieczęć, niezmienny obraz, granica i myśl Ojca"23. Grzegorz wymienia zatem szereg przymiotów negatywnych i pozytywnych odnoszących się do Logosu, które przejął od swoich poprzedników, a które częściowo pochodzą od Platona ${ }^{24}$. Niektóre z nich mają pochodzenie biblijne ${ }^{25}$. Nie tworzy więc pojęć nowych, lecz posługuje się tymi, które mieszkańcom stolicy Cesarstwa powinny być dobrze znane i właściwie rozumiane.

19 Taki podział zaprezentował Orygenes w dziele $O$ zasadach. Najpierw przedstawił wykład o Chrystusie w ramach nauki o Trójcy Świętej (I 2, 1-13), a potem o wcieleniu Chrystusa w kontekście całej ekonomii zbawienia (II 6, 1-6).

${ }^{20}$ Por. A. Houssiau, Incarnation et communion selon les Pères Grecs, "Irenikon" 45(1972)457-468.

21 To zagadnienie omawia m.in. E. Osborn, Theology and Economy in Gregory the Theologian, w: H.C. Brennecke - E.L. Grasmück - C. Markschies (red.), Logos. Festschrift für Luise Abramowski zum 8. Juli 1993, Berlin-New York 1993, 361-383; J. Plagnieux, Saint Grégoire de Nazianze Théologien, Paris 1951, 165-196.

22 Por. Oratio 38, 9-13, SCh 358, 120-132, Mowy, s. 419-421.

23 Oratio 38, 13, SCh 358, 132, w. 14-19, Mowy, s. 421.

${ }^{24}$ Pochodzenie poszczególnych przymiotów dokładnie omawia L. Salvatore, L'Oriente greco: dai Cappadoci allo Pseudo Dionigi l'Areopagita, w: E. dal Covolo (red.), Storia della teologia, t. I: Dalle origini a Bernardo di Chiaravalle, Bologna 1995, 316-317.

${ }^{25}$ Są to: światłość (J 8,12; 9,5), życie (J 1,4; 11,25), odbicie, czyli odblask (Hbr 1,3), pieczęć (J 6,27), obraz (Kol 1,15; 2 Kor 4,4). 
Po wyjaśnieniu, kim jest Słowo Boga, Kapadocczyk przechodzi w swym wystąpieniu do kwestii najtrudniejszej, a mianowicie do objaśnienia samego faktu wcielenia, czyli Bożego Narodzenia. W tej sytuacji Grzegorzowi przychodzi z pomocą retoryka, na bazie której postara się przybliżyć ten zbawczy fakt uczestnikom świątecznej liturgii. Odwołując się do ich wiedzy biblijnej, jak i wyobraźni, nauczał, że Słowo Boga:

„staje się czlowiekiem pod każdym względem z wyjątkiem grzechu. Narodził się z Dziewicy, oczyszczonej wprzód przez Ducha Świętego na duszy i ciele [...], a wystąpił jako Bóg z tym, co przybrał na siebie, jako jedność złożona z dwóch przeciwieństw, ciała i ducha, z których jedno ubóstwiało, a drugie zostało ubóstwione. Co za nowy zespół! Co za przedziwne połączenie! Ten, który jest, zaczyna istnieć; stwórca staje się stworzony; niepojęty zostaje ujęty myślącą duszą, mieszczącą się w środku między bóstwem i przyziemnym ciałem" 26 .

Powyższy tekst, o dosyć skondensowanej treści, stanowi zatem wyjaśnienie zasadniczego momentu w ekonomii zbawienia, a mianowicie, kim z natury jest Jezus Chrystus. Jak można zauważyć, biskup opisując tę tak ważną prawdę zbawczą posłużył się również bardzo prostymi sformułowaniami. Nie używa zawiłych terminów filozoficznych, ani takich, które mogłyby być nie znane słuchaczom.

Niezależnie od tych wniosków, w przytoczonym wyżej opisie wcielenia można natomiast dostrzec mikrostrukturę katechezy kerygmatycznej, na którą składają się trzy człony wypowiedzi. W pierwszym z nich, który tworzą słowa: „staje się człowiekiem pod każdym względem z wyjątkiem grzechu. Narodził się z Dziewicy, oczyszczonej wprzód przez Ducha Świętego na duszy i ciele", Grzegorz opiera się na stwierdzeniach biblijnych, wszystkim znanych, stanowiących bezsprzeczną bazę do przeprowadzenia komentarza, którym jest wypowiedź tworzącą człon drugi: ,a wystąpił jako Bóg z tym, co przybrał na siebie, jako jedność złożona z dwóch przeciwieństw, ciała i ducha, z których jedno ubóstwiało, a drugie zostało ubóstwione". Nie ulega wątpliwości, że mówca pragnie zwrócić uwagę słuchaczy na obecność dwóch natur w Jezusie

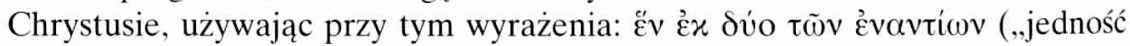
z dwóch przeciwieństw”), którymi są ciało i duch. Używa słowa „ciało”, czyli $\sigma \alpha ́ \varrho \xi$, w rozumieniu judaistycznym, oznaczającego kompletną istotę ludzką, co

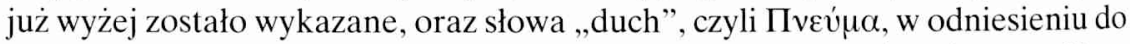
Logosu. W tym kontekście natomiast nie pojawia się słowo фúøı (,natura”) na oznaczenie dwóch natur w Chrystusie, choć słowo to w Mowie 38, która poświęcona jest Bożemu Narodzeniu, występuje jedenaście razy, nigdy jednak w odniesieniu do Chrystusa. Natomiast wzajemne powiązanie tych natur obrazują słowa ,,jedno ubóstwiało, a drugie zostało ubóstwione”, kryjące w sobie

${ }^{26}$ Oratio 38,13 , SCh $358,132-134$, w. 21-30, Mowy s. 421-422. 


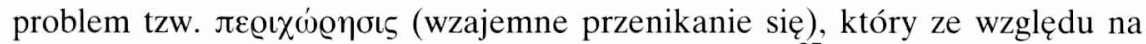
swą złożoność wymaga jednak osobnego opracowania ${ }^{27}$.

Treść wyakcentowanego tu członu drugiego to osobista interpretacja Grzegorza dokonana przy pomocy zabiegów retorycznych, będąca przygotowaniem do zrozumienia treści członu trzeciego, który brzmi następująco: „Co za nowy zespół! Co za przedziwne połączenie! Ten, który jest, zaczyna istnieć; stwórca staje się stworzony; niepojęty zostaje ujęty myślącą duszą, mieszczącą się w środku między bóstwem i przyziemnym ciałem”. W tym tekście bez wątpienia uwagę czytelnika przykuwa pojawienie się dwóch słów, którymi są: $\mu$ íı

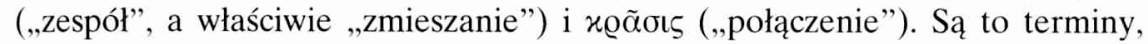
którymi posługiwano się już w grece klasycznej, stosowane w codziennych czynnościach na określenie wszelkiego łączenia lub mieszania, z tym jednak, że wyraz

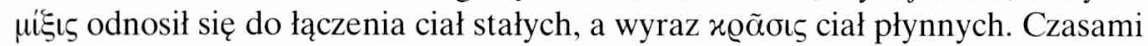
jednak używano ich zamiennie lub wymieniano razem obok siebie. Okazuje się, że te dwa słowa zaczerpnięte z codziennego życia zrobiły swego rodzaju „karierę" w dwóch szkołach filozoficznych, mianowicie Arystotelesa i stoików, w rozważaniach na temat jedności fizycznej zmieszanych ze sobą ciał stałych lub płynnych. Badania porównawcze odpowiednich tekstów tych szkół wykazały, że Arystoteles pod pojęciem zmieszania rozumie nie zestawienie obok siebie dwóch rzeczy, lecz powstanie czegoś trzeciego, natomiast stoicy byli przeciwnego zdania, uważając, że tego typu zmieszanie jest sumą składowych części, zestawionych ze sobą ${ }^{28}$. Słowo to, stosowane najpierw w twórczości Filona, zostało następnie przejęte przez pisarzy wczesnochrześcijańskich z zastosowaniem obydwóch orientacji. W IV wieku przewagę zdobyła interpretacja Stoików, która była znana także Grzegorzowi z Nazjanzu ${ }^{29}$. W tym to właśnie sensie słowa

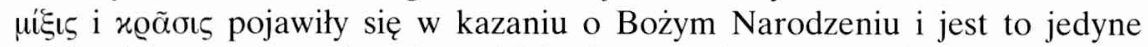
miejsce ich zastosowania w kontekście chrystologicznym, gdyż nieco wcześniej w tejże mowie biskup użył słowa $\mu i \xi ı \varsigma$ w odniesieniu do człowieka złożonego

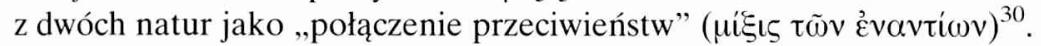

Skoro więc słowa te odegrały niemałą rolę w najwcześniejszym okresie twórczości patrystycznej, chociaż nie przyjęły się jednak w późniejszej terminologii teologicznej ${ }^{31}$, warto przyjrzeć się bliżej, jak funkcjonują w spuściźnie literackiej Grzegorza z Nazjanzu. Otóż słowo $\mu$ íłı zostało przez niego zastosowane siedemnaście razy w mowach i trzynaście razy w poematach, natomiast

${ }^{27}$ Por. H.A. Wolfson, The Philosophy of the Church Fathers. Faith, Trinity, Incarnation, Cambridge - Massachusetts - London, 1976, 421-428; J.P. Egan, Toward Trinitarian Perichoresis: Saint Gregory the Theologian. Oration 31, 14, GOThR 39(1994)199-210.

${ }^{28}$ Szerzej zob. H.A. Wolfson, dz. cyt., 374-382.

29 Tamze, 387-397.

30 Por. Oratio 38, 11, SCh 358, 124, w. 5, Mowy, s. 420.

31 Por. J.N.D. Kelly, Początki doktryny chrześcijańskiej, tłum. J. Mrukówna, Warszawa 1988, 223. 
słowo x@ãoı siedem razy w mowach i cztery razy w poematach. Jeśli przyjąć rok 379 jako cezurę czasową, ponieważ wówczas powstała Mowa 38 o wcieleniu, to nasuwa się pytanie o stosowanie tych słów w osiemnastoletniej działalności przedkonstantynopolitańskiej Grzegorza, w czasie której powstało dziewiętnaście mów. Okazuje się, że dla niego słowo $\mu$ ' $\xi$ ı wcale nie było obce, bo pojawia się w tym okresie siedem razy. Najbardziej charakterystyczne jest to, że pierwsze użycie przez niego słowa $\mu i \xi ı \varsigma$ odnosi się właśnie do Chrystusa. Występuje ono w Mowie 2, wyżej już wzmiankowanej, w kontekście przedstawiania dziejów zbawienia, gdzie punktem kulminacyjnym jest Chrystus i Jego wcielenie. Młody wówczas kapłan i początkujący mówca tak wyjaśniał cel porządku zbawczego:

„Do tego zmierzało zniżenie się boskości, przyjęcie człowieczeństwa i nowe połączenie, z którego powstał Bóg-człowiek, jedna rzeczywistość utworzona z dwóch natur w jednej osobie. Dlatego Bóg zstąpił w ciało za pośrednictwem duszy i połączyły się dwie skłócone natury, dzięki pokrewieństwu z każdą z nich tego, który stał się pośrednikiem. Wszystko zeszło się w jedno dla [nowej harmonii] wszystkiego i dla jednego naszego praojca" ${ }^{32}$.

Zatem dwie natury, boskość i człowieczeństwo, które Grzegorz oddaje słowami

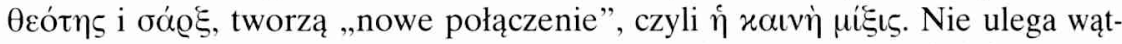
pliwości, że w tym przypadku Kapadocczyk nawiązal do wypowiedzi poprzedników, korzystając z terminu występującego w ich dziełach. Nie wiadomo, czy był wtedy zrozumiany przez słuchaczy. $\mathrm{Z}$ tego powodu, że Mowa 2 nie została wygłoszona w całości, mógł pozwolić sobie na sięgnięcie do tradycji, bez konfrontowania tych zapożyczeń z poziomem wiedzy religijnej swego środowiska. Przytoczony tekst zwraca ponadto uwagę czytelnika na nieustanne akcentowanie obecności dwóch natur, co mogłoby sugerować, że do Nazjanzeńczyka dotarła już błędna koncepcja współistnienia dwóch natur w Chrystusie, głoszona przez Apolinarego. Wówczas gdy Grzegorz układał powyższy tekst, był młodym człowiekiem, mającym 32 lata, który niedawno powrócił do domu po wieloletnich studiach (wiosna 359 r.), a od Bożego Narodzenia 361 roku, czyli od kilku miesięcy, był kapłanem ${ }^{33}$. Tego samego roku Apolinary został biskupem, a w następnym, tj. w 362, jego błędna nauka o wcielonym Chrystusie została potępiona na synodzie aleksandryjskim ${ }^{34}$. Dlatego też Grzegorz wypowiada się ostrożnie, w lapidarnych sformułowaniach, bez wplatania w tok mowy spekulatywnych słów: występujące na przykład w polskim tłumaczeniu zdanie ,jedna rzeczywistość utworzona z dwóch natur” brzmi krótko: हैv $\varepsilon \xi \xi$

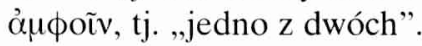

32 Oratio 2, 23 SCh 247, 120, w. 3-9, Szymusiak, Grzegorz Teolog, dz. cyt., 264.

33 Por. Szymusiak, Grzegorz. Teolog, dz. cyt., 120.

${ }^{34}$ Por. tenze, Apolinaryzm, EK I 773. 
Kontynuując rozpoczęty wątek o wcieleniu w Mowie 2, Grzegorz dodaje, że konsekwencją tego „nowego połączenia” jest:

„,nowy porządek oparty na miłości Bożej do człowieka w losach tego, który upadł na skutek nieposłuszeństwa. Dlatego [Boże] narodzenie i Dziewica, dlatego żłobek i Betlejem: narodzenie przypomina pierwotne stworzenie, Dziewica - Ewę, Betlejem - Eden, żłobek - raj, rzeczy małe i widoczne - wielkie i ukryte" ${ }^{\circledR 3}$.

Powyższe cytaty z Mowy 2 to dwa większe fragmenty przytoczone z jednego passusu, poświęconego zbawczej interwencji Boga poprzez wcielenie Syna Bożego. W mowach okresu przedkonstantynopolitańskiego nie pojawiła się już tak długa refleksja Grzegorza o wcieleniu, czyli aż do chwili wygłoszenia Mowy 38 w stolicy Cesarstwa. Porównując tę właśnie refleksję z Mowy 2 z katechezą o wcieleniu zawartą w Mowie 38, można zauważyć, że stanowi ona bardzo zwięzłą i treściowo skondensowaną naukę o wcieleniu, którą Grzegorz później jako biskup Konstantynopola powtórzył, szerzej jednak interpretując poszczególne człony tej refleksji i wyjaśniając je w sposób przystosowany do poziomu wiedzy i wiary chrześcijan stolicy. Innymi słowy, struktura treściowa poszczególnych elementów tych dwóch redakcji jest taka sama, nawet niektóre słowa i sformułowania są identyczne, chociażby na przykład wyżej

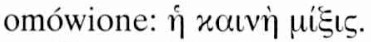

Wprawdzie Grzegorz przed udaniem się do Konstantynopola kilka razy jeszcze wspomniał w swoich wystąpieniach o narodzeniu Chrystusa, jednak były to jedynie pojedyncze zdania na tle szerszego kontekstu. I tak w Mowie 7, wygłoszonej na cześć swego zmarłego brata Cezarego, mówi o Bogu, „który dla nas stał się człowiekiem i wstąpił w naszą nędzę, by dźwignąć ciało i ocalić swój obraz, by na nowo stworzyć człowieka"36, a w Mowie 14, wygłoszonej do biednych, poucza o Jezusie, który „także stał się człowiekiem”,37, „zrodzony z dziewicy, aby i narodzenie uczcić i dziewictwo wyżej postawić"38 , zaś w Mowie 19 wygłoszonej w obecności komisarza podatkowego Juliana, cytując lub parafrazując biblijne opisy związane z przyjściem Chrystusa na świat, przemawia: „I w tym czasie - o cudzie! - rodzi się Zbawiciel, Stwórca i Pan wszechrzeczy, w marnym i małym schronisku. Lękajmy się tej tajemnicy, uszanujmy dzieło wcielenia i sami ofiarujmy coś temu czasowi” 39 i nieco dalej: ,,Teraz Chrystus rodzi się dla ciebie, jest Bogiem, a staje się człowiekiem i z ludźmi obcuje"40.

Jak już stwierdzono, Grzegorz w okresie przedkonstantynopolitańskim słowo $\mu$ íફıら użył jeszcze sześć razy, stosując je w odniesieniu do człowieka lub

35 Oratio 2, 24, SCh 247, 120-122, w. 39, Szymusiak, Grzegorz Teolog, dz. cyt., 264.

${ }^{36}$ Oratio 7, 23, SCh 405, 240, w. 16-19, Szymusiak, Grzegorz Teolog, dz. cyt., s. 303.

${ }^{37}$ Oratio 14, 2, PG 35, 860 D, Mowy, s. 167.

38 Oratio 14, 3, PG 35, 861 B, Mowy, s. 168.

39 Oratio 19, 12, PG 35, 1057 B, Mowy, s. 214.

40 Oratio 19, 13, PG 35, 1057 D, Mowy, s. 215. 
przyrody. Czterokrotnie występuje ono wraz ze słowem x@đ̃oıక w następują-

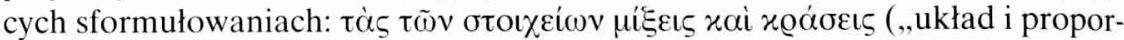

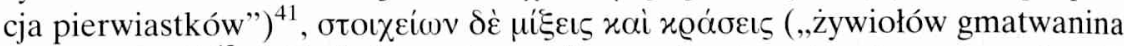

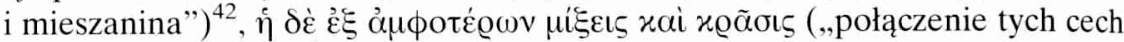

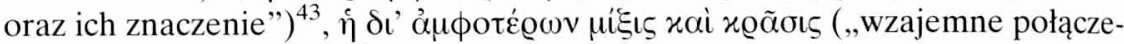
nie jednego z drugim" $)^{44}$ oraz dwukrotnie samodzielnie w następujących wy-

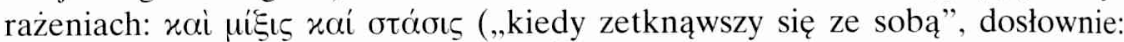
,jako połączenie i stan nieruchomy”) ${ }^{45}, \grave{\eta} \theta \alpha v \mu \alpha \sigma i \alpha \mu \mu^{\prime} \xi \iota \varsigma$ („owo dziwne spotkanie" $)^{46}$. Wnioskować z tego można, że było to popularne słowo, używane

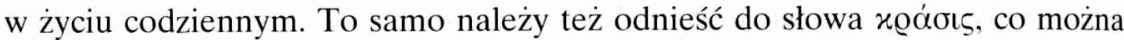
zauważyć w podanych kontekstach jego użycia. Obok tych czterech już wyszczególnionych zastosowań tego terminu piąty raz występuje w wyrażeniu

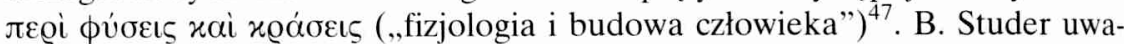
$\mathrm{ża}^{48}$, że w tych słowach - używanych w kontekście natur Chrystusa - nie ma żadnych spekulacji filozoficznych, lecz posiadają one prawdziwe odniesienie do życia chrześcijańskiego, konkretyzujące się w przebóstwieniu człowieczeństwa przez Chrystusa.

Kolejny etap rozważań katechetycznych o Bożym Narodzeniu w Mowie 38 poświęcił Grzegorz ukazaniu motywów wcielenia, uznając je za warte uzmysłowienia słuchaczom. W trosce o nich głosił, że Słowo Boga:

„idzie do własnego obrazu, przyjmuje ciało z powodu ciała, dla mojej duszy łączy się z myślącą duszą, aby podobnym oczyścić podobne, [...], bierze na siebie żebractwo mojego ciała, abym ja się wzbogacił Jego boskością. [...], na krótki czas pozbywa się swej chwały, abym ja miał udział w Jego pełności. Co to za bogactwo dobroci? Co to za misterium mnie dotyczące? Otrzymałem pierwej uczestnictwo w obrazie Bożym i nie ustrzegłem go; On przyjmuje uczestnictwo w moim ciele, aby i obraz ocalić, i ciało unieśmiertelnić" ${ }^{49}$.

W zacytowanym tekście można dostrzec myśli, które zostały przez Grzegorza wypowiedziane już wcześniej. Te dosyć lapidarne wypowiedzi wówczas wygłoszone biskup łączy teraz w dłuższe rozważanie, by tym sposobem szerzej przedstawić konieczność wcielenia Chrystusa, a u słuchających spowodować pogłębienie ich wiary w odkupienie.

${ }^{41}$ Oratio 2, 29, SCh 247, 128, w. 10-11, Szymusiak, Grzegorz Teolog, dz. cyt., s. 266.

42 Oratio 6, 15, SCh 405, 160, w. 14-15, Mowy, s. 142.

43 Oratio 2, 54, SCh 247, 162, w. 3, Szymusiak, Grzegorz Teolog, dz. cyt., s. 273.

44 Oratio 6, 2, SCh 405, 124, w. 24-25, Mowy, s. 135.

45 Oratio 4. 49. SCh 309. 152, w. 3, Mowy, s. 80.

46 Oratio 4. 116, SCh 309, 278, w. 10, Mowy, s. 109.

${ }^{47}$ Por. Oratio 7, 7, SCh 405, 194, w. 19, Szymusiak, Grzegorz Teolog, dz. cyt., s. 294.

48 Por. Dio Salvatore nei Padri della Chiesa. Trinità cristologia-soteriologia, Roma 1986, 275.

49 Oratio 38, 13, SCh 358, 132-134, w. 19-37, Mowy, s. 421-22. 
Z tajemnicą wcielenia ściśle bowiem połączona jest - na co wskazują powyższe słowa - tajemnica odkupienia ${ }^{50}$. W ujęciu Grzegorza wcielenie jest zapoczątkowaniem zbawienia, które polega na przebóstwieniu człowieka (,abym ja się wzbogacił Jego boskością”) ${ }^{51}$, czego następstwem jest ocalenie obrazu, czyli duszy, oraz unieśmiertelnienie ciała (,,aby i obraz ocalić, i ciało unieśmiertlelnić"). Składają się na to wszystkie akty działalności publicznej Chrystusa, które w dalszym ciągu Mowy 38 Grzegorz wymienia i określa jako „zbawienie grzeszników” ( $\sigma \omega \tau \eta ̣ i \alpha ~ \alpha ́ \alpha \alpha \varrho \tau \omega \lambda \tilde{\omega} \nu)^{52}$. Wyliczanie aktów zbawczych Chrystusa biskup kończy na wymienieniu tych decydujących: ukrzyżowaniu, pogrzebaniu, zmartwychwstaniu, wstąpieniu do nieba ${ }^{53}$. Wykorzystując okazję, jaką było święto Bożego Narodzenia, Grzegorz wyłożył istotę chrystologii: fakt wcielenia zwieńczył aktami paschalnymi. Z tego też względu tak dokładne opracowanie tej tajemnicy, ujętej w szerokiej perspektywie porządku zbawienia, powtórzył w mowie na Wielkanoc w 383 roku ${ }^{54}$.

Ostatni passus Mowy 38 ma charakter zdecydowanie parenetyczny. Mówca zachęca do naśladowania Chrystusa, bo tylko wtedy można być Jego prawdziwym uczniem. Słowa biskupa wzywają do niezwykle radykalnej postawy, by opowiedzieć się za Chrystusem bez względu na okoliczności, w jakich się znajdzie człowiek. To wezwanie skierowane do uczestników liturgii jest także istotnym elementem katechezy o wcieleniu Chrystusa ${ }^{55}$.

Tak rzetelnej i wieloaspektowej katechezy na temat tajemnicy wcielenia Grzegorz już potem nie wygłosił (poza powtórzeniem wspomnianego wyżej fragmentu Mowy 38 na Wielkanoc 382 r. w Nazjanzie w Mowie 45). Owszem, niejednokrotnie w późniejszych mowach często przypominał słuchającym o przyjściu na ziemię Zbawiciela, jednak były to krótkie stwierdzenia tego faktu bez szerszej analizy katechetycznej ${ }^{56}$ lub też niewielkie opisy znaczenia

50 To zagadnienie w całej twórczości Grzegorza z Nazjanzu omówił L. Stephan, Soteriologie des hl. Gregor von Nazianz, Roma 1938.

${ }^{51}$ Por. D.F. Winslow, The Dynamics of Salvation. A Study in Gregory of Nazianzus, Phila-

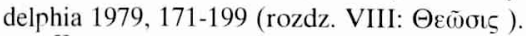

52 Por. Oratio 38, 14, SCh 358, 138, w. 29, Mowy, s. 422.

53 Grzegorz z Nazjanzu akty zbawcze Chrystusa przeplata wypowiedziami polemizującymi, karcąc tych, którzy znieważają Jego ciało i odbierają Mu bóstwo: Oratio 38, 14-16, SCh 358, 134 142, Mowy, s. 422-423.

${ }^{54}$ Por. Szymusiak, Grzegorz Teolog, dz. cyt., s. 174. Tekst z Oratio 38, 6-13 (SCh 358, 114-134) powtórzony został w Oratio 45, 2-9 (PG 36, 625 B - 636 A), natomiast jego kontynuacja z Oratio 38 , 14-15 (SCh 358, 134-140) została powtórzona w Oratio 45, 26-27 (PG 36, 657 C - 661 A).

55 Szerzej o tym zob.: N. Widok, Grzegorz z Nazjanzu o Bozym Narodzeniu. Aspekty liturgiczne i chrystologiczne „Mowy 38”, w: T. Dola - R. Pierskała (red.), Ut mysterium paschale vivendo exprimatur. Księga pamiątkowa dedykowana Księdzu Profesorowi Helmutowi Janowi Sobeczce z okazji 60. rocznicy urodzin, Opole 2000, 250-251.

${ }^{56}$ Por. następujące miejsca w mowach Grzegorza: Oratio 21, 3 (Mowy, s. 227, SCh 270, 116, w. 13); Oratio 28, 3 (Mowy, s. 287, SCh 250, 104, w. 6-7); Oratio 30, 6 (Mowy, s. 331, SCh 250, 236, w. 7-13); Oratio 30, 8 (Mowy, s. 333, SCh 250, 240, w. 3-5); Oratio 30, 14; (Mowy, s. 338, SCh 250, 
wcielenia w ramach szerzej przedstawianej ekonomii zbawczej ${ }^{57}$. W tych ostatnich dostrzec można tę samą zasadę katechetyczną, którą Grzegorz zastosował w Mowie 38, to znaczy nie wyszukując trudnych słów, w sposób przystępny dla przeciętnego słuchacza objaśniał sens tego wydarzenia zbawczego.

Ten sposób wykładu zdecydowanie różni się od tego, który zaprezentował Kapadocczyk w listach pisanych do Kledoniusza prezbitera zarządzającego Kościołem w Nazjanzie ${ }^{58}$. W nich na prośbę Kledoniusza o przedstawienie nauki na temat apolinaryzmu ${ }^{59}$, Grzegorz w sposób syntetyczny wyłożył naukę o wcieleniu ${ }^{60}$, posługując się już językiem bardzo precyzyjnym z zastosowaniem

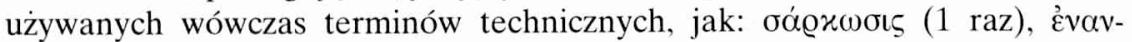

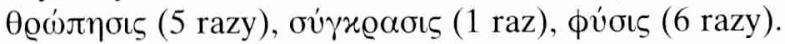

Nauczanie kerygmatyczne, które ma nawiązywać do wydarzenia zbawczego dokonanego przez Boga w Jezusie Chrystusie, wówczas osiąga skutek, gdy przekazywane jest w sposób odpowiadający mentalności ludzi danych czasów $^{61}$. Powyższa analiza Mowy 38 w pełni tego dowodzi. Grzegorz w swoim wykładzie chrystologicznym prawie zupełnie nie posługuje się terminami z ówczesnego języka teologicznego. W całej omawianej mowie, która przecież poświęcona jest Bożemu Narodzeniu, tylko jeden raz użył słowa „wcielenie” $(\sigma \alpha ́ \varrho x \omega \sigma \iota \varsigma)^{62}$, a jedenaście razy słowa „natura” ( $\left.\phi \dot{\sigma} \sigma \iota \zeta\right)$, nigdy jednak w kontekście natur Chrystusa. Chcąc natomiast wyjaśnić, że Jezus Chrystus ma dwie

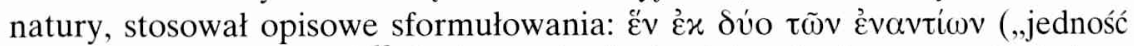

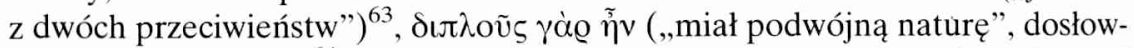
nie: „był podwójny” $)^{64}$. Tajemnicę wcielenia nazywał innymi terminami, wyżej

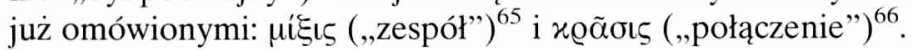

O takim postępowaniu Grzegorza bez wątpienia zadecydowała atmosfera dość burzliwych dyskusji teologicznych w Konstantynopolu. Nowo przybyły biskup nie chciał swymi wyjaśnieniami jeszcze bardziej rozdrażniać rozmaitych

256, w. 10-13); Oratio 40, 2 (Mowy, s. 437, SCh 358, 200, w. 13); Oratio 40, 38 (Mowy, s. 458, SCh 358, 286, w. 22-23); Oratio 43, 62 (Mowy, s. 511, SCh 384, 258, w. 2-6).

57 Są to następujące teksty: Oratio 29, 18-19 (Mowy, s. 323-324, SCh 250, 214-218); Oratio 39 , 13 (Mowy, s. 431, SCh 358, 176-178); Oratio 40, 45 (Mowy, s. 462, SCh 358, 304-306, w. 21-37).

${ }^{58}$ Por. List 101 z 382 r. i List 102 z lat 384-386, thum. J. Stahr, POK 15, 130-152; Szymusiak, Grzegorz Teolog, dz. cyt., s. 239.

59 Por. J. Dräseke, Gregor von Nazianz und sein Verhältnis zum Apollinarismus, ThSK 65(1892) 473-512.

${ }^{60}$ Opis zasadniczych myśli nauki Grzegorza o tej tajemnicy przedstawił S. Longosz, Chrystologia Ojców Kapadockich VoxP 17(1997)166-176.

${ }_{61}$ Por. B. Forte, Kerygma. II. Systematisch-theologisch, LThK V 1409-1410.

${ }^{62}$ Por. Oratio 38, 3, SCh 358, 108, w. 9.

63 Por. Oratio 38,13 , SCh 358,134 , w. 26.

${ }^{64}$ Por. Oratio 38,15 , SCh 358,138 , w. 1.

${ }^{65}$ Por. Oratio 38,13 , SCh 358,134 , w. 27. Drugi raz tego samego słowa użył w odniesieniu do człowieka, posiadającego duszę i ciało: Oratio, 38, 11, SCh 358, 124, w. 5.

66 Por. Oratio, 38, 13, SCh 358, 134, w. 28. 
frakcji dyskutantów, zwłaszcza tych, których poglądy graniczyły z herezją. Każde nowe słowo tworzącego się języka chrystologicznego dostarczało bowiem polemizującym grupom wiele powodów do waśni i zacietrzewień, a tego biskup stolicy chciał uniknąć za wszelką cenę. Nie mógł też za bardzo wznosić się na wyżyny spekulacji filozoficznych, gdyż przemawiał w większości do ludzi prostych. Jako retor wykorzystał natomiast bogate słownictwo języka greckiego do przedstawienia, i to w sposób barwny, tajemnicy wcielenia. Grzegorz z Nazjanzu dążył do wyjaśnienia istoty tego faktu ekonomii zbawienia przy użyciu prostych określeń, unikając przy tym ujęć ściśle spekulatywnych.

Bulla ogłaszająca Wielki Jubileusz Roku 2000 Incarnationis mysterium Jana Pawła II wzywa chrześcijan do przeżywania tego szczególnego Roku w duchu uwielbienia i wdzięczności. Papież uświadamia wszystkim wyznawcom Jezusa Chrystusa, by Rok Święty był ,jednym nieprzerwanym hymnem uwielbienia Boga w Trójcy Jedynego" (3) i odwołuje się do Teologa z IV wieku - Grzegorza z Nazjanzu, przytaczając słowa jego hymnu uwielbienia Trójcy Przenajświętszej za wcielenie Syna, które powinni razem wznieść wszyscy wyznający tę samą wiarę w Pana Jezusa:

"Chwała Bogu Ojcu i Synowi,

Królowi wszechświata.

Chwała Duchowi,

bo godzien jest czci i wszystek święty.

Trójca jest jednym Bogiem,

który wszystko stworzył i napełnił:

niebo istotami niebieskimi,

a ziemię istotami ziemskimi.

Morze, rzeki i strumienie napełnił

zwierzętami wodnymi,

ożywiając wszystko swoim Duchem,

aby wszelkie stworzenie śpiewało

hymn chwały mądremu Stwórcy,

jedynej przyczynie życia i trwania.

Nade wszystko zaś niech zawsze

wielbi Go stworzenie rozumne

jako wielkiego Króla

i dobrego Ojca" ${ }^{, 67}$.

67 Por. Bulla Incarnationis Mysterium 3, nota 9: „Poematy dogmatyczne, XXXI, Hymnus alias: PG 37, 510-511". 


\section{CHERYGMATICUS INSTITUTIONIS MODUS DE INCARNATIONE APUD GREGORIUM NAZIANZENUM}

(Argumentum)

Quia Constantinopoli multi Arii et praesertim Apollinarii sectatores versabantur, Gregorius Nazianzenus tamquam episcopus illius urbis veram doctrinam de Incarnatione exponere christianis ob religiosas disputationes confusis voluit. Persaepe docebat ibi de Christo nato in duabus naturis. Potissimum hanc doctrinam perpendit ille in Oratione 38 , quae in antiquis litteris christianis prima nobis nota tractatio de Nativitate Domini est. Gregorius in enodando de Incarnatione voces philosophicas non adhibebat, sed quaestiones ad Christi Nativitatem pertinentes cum descriptionibus apertis perspicuisque illustrabat. Huiusmodi institutio cherygmaticum modum in se habet. 